\title{
Food Security Assessment: A GIS-based Mapping of Food Sufficiency in Kalimantan Utara, Indonesia
}

\author{
Rika Harini $^{1}$ and Bowo Susilo ${ }^{2}$ \\ ${ }^{1}$ Department of Environmental Geography, Faculty of Geography, Universitas Gadjah Mada \\ ${ }^{2}$ Department of Geographic Information Science, Faculty of Geography, Universitas Gadjah Mada
}

\begin{abstract}
Food security is considered as one of integrated aspects related to disaster risk management. The objective of the study was to assess food security, by means of mapping the food sufficiency, in Kalimantan Utara Province, Indonesia. The sufficiency of food were analyzed using Index of food availability $\left(I_{A V}\right)$, which is the ratio between net food production and normative food consumption. Based on the values of $I_{A V}$, food sufficiency were classified into three categories i.e. minus, sufficient and surplus. The classification referred to Indonesian Food Security Agency. GIS was utilized to mapping the spatial distribution of agricultural land as well as the food suficiency. This study shows that at provincial level, food sufficiency in Kalimantan Utara is in the surplus category $\left(I_{A V}=1.15\right)$. However, at district level the index varies between 0.1 and 2.78. Among five districts within the province, three districts i.e. Malinau, Bulungan and Nunukan were in category surplus, while Nunukan and Tarakan were in category sufficient and minus respectively.
\end{abstract}

Key Words: Food Security, Food Sufficiency, GIS, Mapping

\section{Introduction}

Food security is considered as one of integrated aspects related to disaster risk management (FAO Disaster Risk Management Working Group). Since climate change is now affecting global agriculture and food production worldwide (Ye et al, 2015), food security assessment may provide useful information to improve preparedness before disaster occurs. Food and agriculture sectors can play a key role in increasing the resilience of vulnerable populations to crises and help people recover (FAO).

Food security has four dimension i.e. availability, accessibility, stability and utilization (FAO, 2008; Leroy et al, 2015). Assessment of food security can be measured at different levels, including at the community, national, regional, and global levels (Leroy et al, 2015). Availability and access dimension of food security can be assessed at all levels. Indonesia Ministry of Agriculture, trough National Food Security Agency, had provide guidance to asses food security in term of food availability (BKPRI, 2014).

Kalimantan Utara is the youngest province in Indonesia and located at northern part of Kalimantan (Borneo) Island, immediately adjacent to Malaysia. The main land uses in Kalimantan Utara are forest and estate plantation, whereas mining is still the leading sector to support gross domestic product (BPS, 2015). The population in Kalimantaran Utara is low in general, but statistical data shows there is positive trend of population growth. Food crop productions, in another side, fluctuate and tend to decrease in several recently years. Fluctuated food production and increasing number of population become critical issue in relation to food security within which the government attention must be paid. This study aimed to assess food security, by means of mapping the food sufficiency based on food availability. Map of food sufficiency will provide useful information as well as better spatial insight about food security in Kalimantan Utara. 


\section{Methods}

\subsection{Study Area and Data Sets}

Kalimantan Utara Province (Fig. 1) was selected as the study area due to its national importance to agricultural production (rice estate in Nunukan and food estate in Delta Kayan) and strategic geographic position. Kalimantan Utara is the youngest province in Indonesia, formed on 25 October 2012. This province is located in the northern part of Kalimantan (Borneo) Island and immediately adjacent to Malaysian states of Sabah and Sarawak.

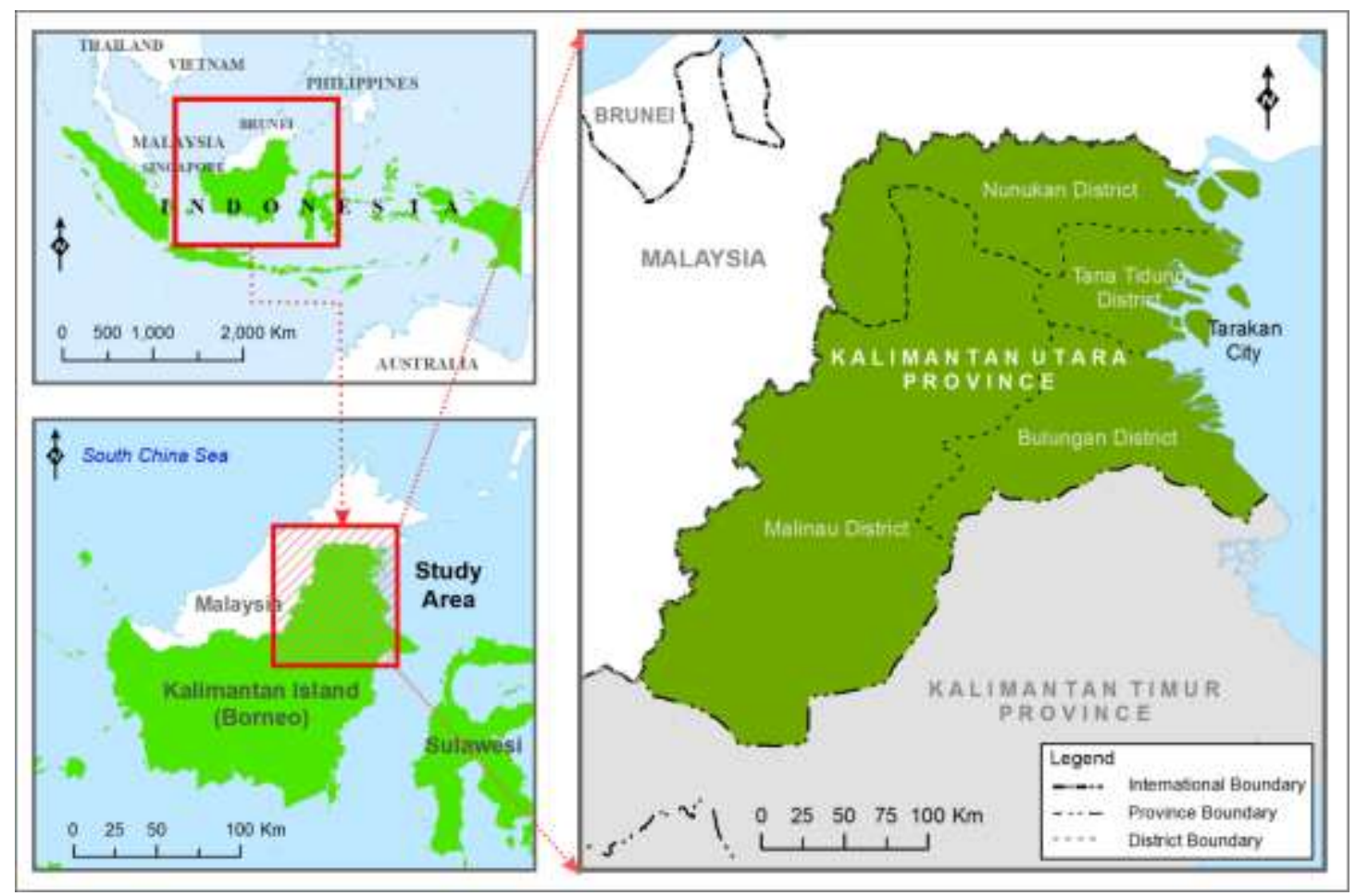

Fig. 1: Study Area: Kalimantan Utara Province, Indonesia

This study used different type of data which obtained from different sources. Tabular data were obtained from book published by local Statistical Bureau. Spatial data i.e. administrative boundary and land use, were obtained from Indonesian Topographic Maps published by Indonesian Mapping Agency.

\subsection{Food Availability Analysis}

In this study, food availability was analyzed based on production of four agricultural crops, i.e. paddy, cassava, maize and sweet potato. Rice is a staple food for almost Indonesian people, while maize, cassava and sweet potato considered as important part of national diet. Food consumption in Indonesia shows that almost 50 percent of the necessary callories are attained from cereals. The availability of food (F) is defined as availability of cereals per capita per day, and calculated by dividing the cereals food production (Pfood) with the mid-year population (Tpopx365).

$$
\mathrm{F}=\text { Pfood } / \text { Tpopx } 365
$$

Equation (2) was used to calculate cereals equivalent food production.

$$
\mathrm{P}_{\text {food }}=\mathrm{R}_{\text {net }}+\mathrm{M}_{\text {net }}+\mathrm{T}_{\text {net }}
$$

The above equation mean that cereals food production is the sum of net production of rice (Rnet), maize (Mnet) and tuber (Tnet). Tubers are comprises cassava (Cnet) and sweet potato (Spnet). The net production for 
each food, was calculated using different equation. Equation (3), (4) and (5) were used to calculate net production of rice, maize and tubers respectively.

$$
\mathrm{R}_{n e t}:\left(\mathrm{P}-\left(s_{p}+f_{p}+w_{p}\right)\right) \mathrm{x}
$$

In the equation (3), Rnet denote the net production of rice, $\mathrm{Pp}$ is gross production of paddy, $\mathrm{sp}$ is seed requirement for paddy plantation (0.009), fp is the use of paddy grain for feeding animals (0.0044), wp is post harvest loss and waste (0.054), and $\mathrm{c}$ is the coefficient of converting paddy to rice $(0.632)$. Note that this coefficient is refer to the United Nation (2014)

$$
\text { Mnet : M - }(\mathrm{sm}+\mathrm{fm}+\mathrm{wm})
$$

In the equation (4), Mnet denote the net production of maize, $M$ is gross production of maize, sm is seed requirement for maize plantation (0.009), fm is the use of maize for feeding animals (0.06) and wm is post harvest loss and waste of maize $(0.05)$

$$
\text { Tnet : } 1 / 3 \times(\text { Cnet }+ \text { SPnet })
$$

In the equation (5), Tnet denote the net production of tubers, Cnet is net production of cassava and SPnet is net production of sweet potato. Cnet and SPnet were calculated using equation 6 and 7 respectively.

$$
\text { Cnet : C }-(\mathrm{sc}+\mathrm{fc}+\mathrm{wc})
$$

In the equation (6), Cnet denote the net production of cassava, $\mathrm{C}$ is gross production of cassava, sc is seed requirement for cassava plantation (0), fc is the use of cassava for feeding animals (0.02) and wc is post harvest loss and waste of cassava (0.00213)

$$
\text { SPnet : SP - ( ssp + fsp + wsp ) }
$$

In the equation (7), SPnet denote the net production of sweet potato, SP is gross production of sweet potato, $\mathrm{ssp}$ is seed requirement for sweet potato plantation (0), fsp is the use of sweet potato for feeding animals (0.02) and wsp is post harvest loss and waste of sweet potato $(0.1)$

\subsection{Food Sufficiency Analysis}

Food sufficiency was analyzed by means of ratio between food availability $(\mathrm{F})$ and normative consumption (Cnorm). The calculation of food availability already explained in previous section. Normative consumption was defined as daily normal consumption of food, to obtain one kilo calories from cereals. Daily normal consumption in Indonesia, according to Indonesian Bureau of Food Security (2014), is equivalent to 300 gram of cereals. The ratio between Fav and Cnorm is termed index of food availability (IAV) which is calculated using equation 8 .

$$
\text { IAV : F / Cnorm }
$$

Based on the values of IAV, food sufficiency was classified into three categories as shown in Table 1. This classification is used by Indonesian Bureau of Food Security (2014).

TABLE I. Classification of food sufficiency based on index of availability

\begin{tabular}{cc}
\hline Index $\left(\mathbf{I}_{\mathbf{A V}}\right)$ & Food Sufficiency \\
\hline$<0,90$ & Minus \\
$0,90-1,14$ & Sufficient \\
$>1,14$ & Surplus
\end{tabular}




\subsection{GIS-based Mapping of the Food Sufficiency}

GIS is used for mapping the spatial distribution of food sufficiency in the study area. Administrative boundary was served as mapping unit. Two different mapping unit, i.e. district and sub district were used for mapping food sufficiency at different level of spatial extent. District is used for mapping at provincial level and sub district is used for mapping at district level.

\section{Result and Discussion}

\subsection{Food Availability}

Food availability in certain area, is determined by food production and number of consumer i.e. number of population in that area. In general, number of population in Kalimantan Utara, during 2014 and 2015, had increase. The same situation occurs to the gross production of food. Number of population varies across district, but almost 37 percent of Kalimantan Utara people were live in Tarakan. Unfortunately the gross production of food in Tarakan is not lined up with the number of population. As shown in Table 2, gross production of food in Tarakan is situated at the second lowest position after Tana Tidung district. In the opposite side, number of population in Tarakan is the highest among others districts in Kalimantan Province.

TABLE II: Population and gross production of food in Kalimantan Utara Province

\begin{tabular}{lrrrrr}
\hline \multirow{2}{*}{ District } & \multicolumn{3}{c}{ Population } & \multicolumn{2}{c}{ Gross production (ton) } \\
\cline { 2 - 6 } & \multicolumn{1}{c}{2014} & \multicolumn{1}{c}{2015} & Mid-year & \multicolumn{1}{c}{2014} & \multicolumn{1}{c}{2015} \\
\hline Malinau & 74,469 & 77,492 & 75,981 & $15,892.03$ & $10,855.44$ \\
Bulungan & 126,096 & 129,381 & 127,739 & $36,938.52$ & $38,862.60$ \\
Tana Tidung & 20,372 & 21,891 & 21,132 & 201.86 & $2,174.82$ \\
Nunukan & 170,042 & 177,607 & 173,825 & $24,580.12$ & $24,651.42$ \\
Tarakan & 227,229 & 235,565 & 231,397 & $6,321.38$ & $6,976.44$ \\
\hline Kalimantan Utara & 618,208 & 641,936 & 630,072 & $83,933.91$ & $83,520.72$ \\
\hline
\end{tabular}

Instead of using gross production, food availability is assessed using net production of food. Table 3 shows cereals and tubers as well as the total net production. Total net production were varies across districts and the highest values was found in Bulungan District. It is interesting to note that Bulungan is not the greatest district in term of area. The greatest district is Malinau, but the quantities of food production in this district is number three. Figure 2 shows the spatial distribution of net production of food and agriculture land in Kalimantan Utara. Those figure provide better visually insight about the spatial relationship between food production and the existence of agriculture land particularly paddy field. Instead of agriculture land, forest is predominant land use in Kalimantan Utara.

TABLE III: Net production of food in Kalimantan Utara Province

\begin{tabular}{|c|c|c|c|c|c|c|}
\hline \multirow[b]{2}{*}{ District } & \multicolumn{2}{|c|}{ Cereals } & \multicolumn{3}{|c|}{ Tubers } & \multirow{2}{*}{$\begin{array}{l}\text { Total Net } \\
\text { Production } \\
\left(\mathrm{P}_{\text {food }}\right)\end{array}$} \\
\hline & $\begin{array}{l}\text { Rice } \\
\left(\mathrm{R}_{n e t}\right)\end{array}$ & $\begin{array}{l}\text { Maize } \\
\left(\mathrm{M}_{n e t}\right)\end{array}$ & $\begin{array}{c}\text { Cassava } \\
\left(\mathrm{C}_{n e t}\right)\end{array}$ & $\begin{array}{l}\text { Sweet } \\
\text { Potato } \\
\left(\mathrm{SP}_{n e t}\right) \\
\end{array}$ & $\begin{array}{l}\text { Total Tubers } \\
\qquad\left(\mathrm{T}_{n e t}\right)\end{array}$ & \\
\hline Malinau & $10,197.56$ & 226.42 & $1,124.56$ & 169.84 & 431,47 & $10,855.44$ \\
\hline Bulungan & $36,285.63$ & 481.03 & $5,201.91$ & $1,085.92$ & $2,095.94$ & $38,862.60$ \\
\hline Tana Tidung & $1,840.45$ & 47.57 & 779.42 & 80.96 & 286.79 & $2,174.82$ \\
\hline Nunukan & $16,576.25$ & 154.18 & $22,934.02$ & 828.96 & $7,920.99$ & $24,651.42$ \\
\hline Tarakan & 82.31 & 0.00 & $7,288.04$ & 343.2 & $2,543.75$ & $2,626.06$ \\
\hline Kalimantan Utara & $64,982.21$ & 909.19 & $37,327.94$ & $2,508.88$ & $13,278.94$ & $79,170.34$ \\
\hline
\end{tabular}



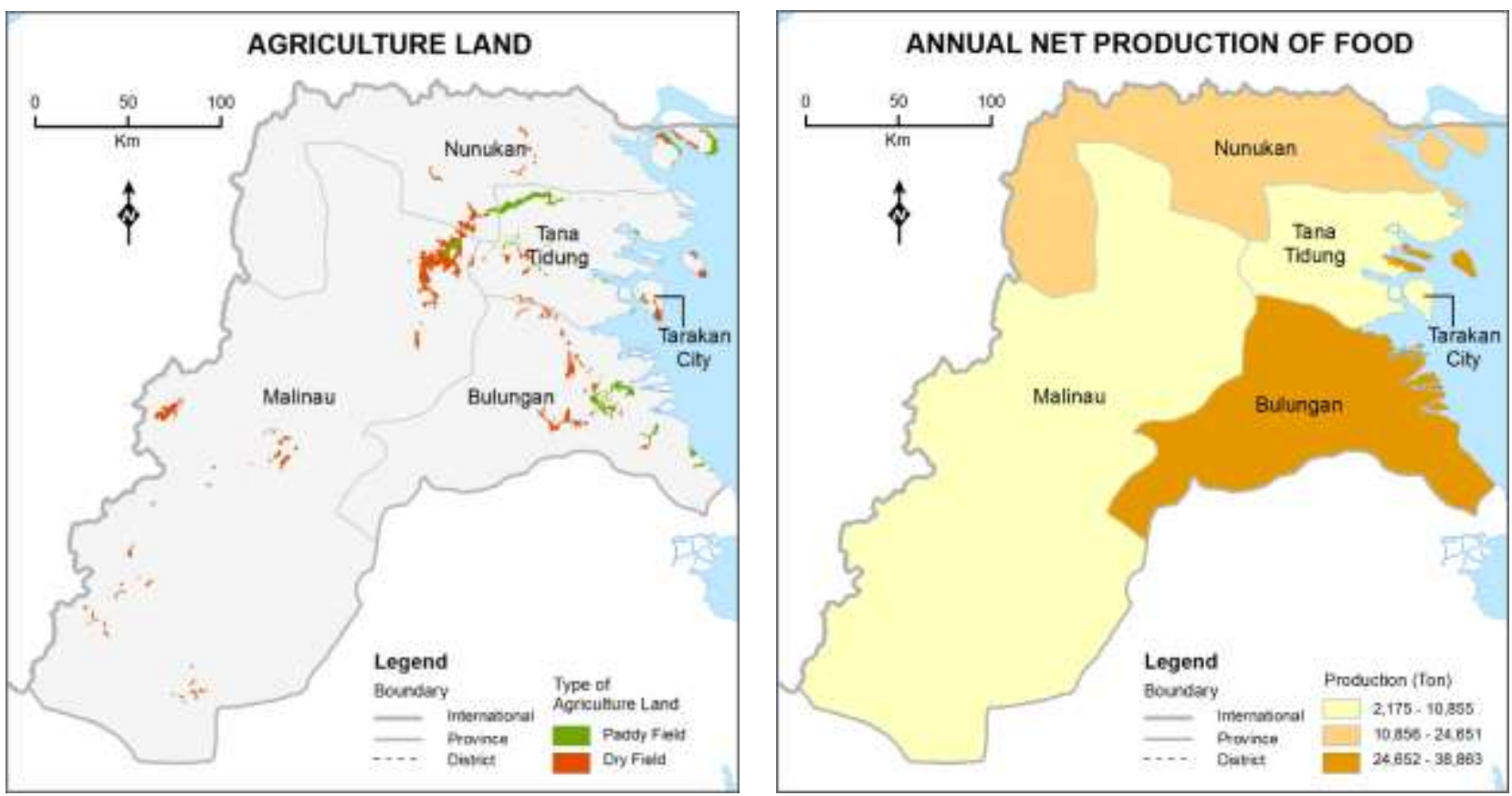

Fig. 2: Spatial distribution of agricultural land inKalimantan Utara (left) and annual net production food (right)

\subsection{Food Sufficiency}

Food sufficiency in Kalimantan Utara for period 2014-2015 was in the category surplus in general. As shown in Table 4, Index of food availability at provincial level was 1.15 , while at district level the index varies between 0.1 and 2.78. Among five districts within the province, three districts i.e. Malinau, Bulungan and Nunukan were in category surplus, while Nunukan and Tarakan were in category sufficient and minus respectively.

TABLE IV: Index of availability and food sufficiency in Kalimantan Utara Province

\begin{tabular}{|c|c|c|c|c|c|c|}
\hline \multirow{2}{*}{ District } & \multicolumn{4}{|c|}{ Parameter } & \multirow{2}{*}{$\mathrm{I}_{\mathrm{av}}$} & \multirow{2}{*}{ Sufficiency } \\
\hline & $\mathrm{P}_{\text {food }}$ & $\mathrm{F}$ (ton) & $\mathrm{F}$ (gram) & $\mathrm{C}$ & & \\
\hline Malinau & $10,855.44$ & 0.00039 & 391.43 & 300 & 1.30 & Surplus \\
\hline Bulungan & $38,862.60$ & 0,00083 & 833.52 & 300 & 2.78 & Surplus \\
\hline Tana Tindung & $2,174.82$ & 0,00028 & 281.97 & 300 & 0.94 & Sufficient \\
\hline Nunukan & $24,651.42$ & 0,00039 & 388.54 & 300 & 1.30 & Surplus \\
\hline Tarakan & $2,626.06$ & 0,00003 & 31.09 & 300 & 0.10 & Minus \\
\hline Kalimantan Utara & $79,170.34$ & 0,00034 & 344.25 & 300 & 1.15 & Surplus \\
\hline
\end{tabular}

Tarakan District is a small island which is separated from main island of Kalimantan. The district comprise four sub districts namely Tarakan Utara, Tarakan Tengah, Tarakan Barat and Tarakan Timur. As shown in Table 5, food sufficiency in all sub districts were in category minus except Tarakan Utara sub district. Figure 3 shows spatial distribution of food sufficiency in Kalimantan Utara Province and at Tarakan District. 

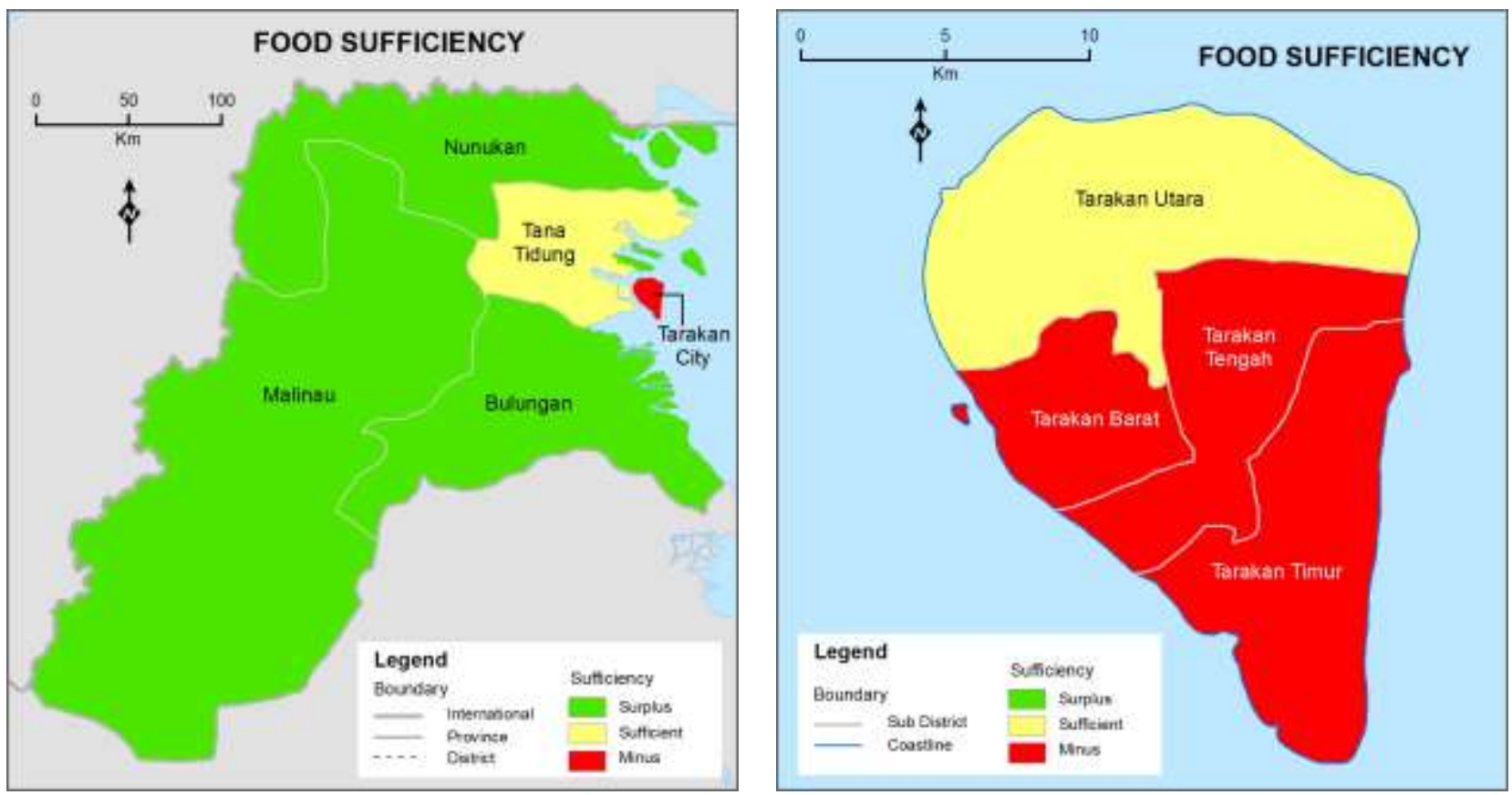

Fig. 3: Map of food sufficiency at provincial and district level : Kalimantan Utara province (left) and Tarakan district (right)

TABLE V: Index of availability and food sufficiency in Tarakan Districts

\begin{tabular}{lccrrrll}
\hline \multirow{2}{*}{ Sub District } & \multicolumn{9}{c}{ Parameter } & \multirow{2}{*}{$\mathrm{I}_{\mathrm{av}}$} & \multirow{2}{*}{ Sufficiency } \\
\cline { 2 - 5 } & $\mathrm{P}_{\text {food }}$ & $\mathrm{F}$ (ton) & $\mathrm{F}$ (gram) & $\mathrm{C}$ & & \\
\hline Tarakan Timur & $1,706.97$ & 0.00009 & 92.34 & 300 & 0.31 & Minus \\
Tarakan Tengah & $1,038.68$ & 0.00004 & 39.84 & 300 & 0.13 & Minus \\
Tarakan Barat & $1,824.07$ & 0.00006 & 62.60 & 300 & 0.21 & Minus \\
Tarakan Utara & $2,575.54$ & 0.00027 & 271.68 & 300 & 0.91 & Sufficient \\
\hline Tarakan & $7,166.99$ & 0.00009 & 86.17 & 300 & 0.29 & Minus \\
\hline
\end{tabular}

\section{Conclusion}

The sufficiency of food in Kalimantan Utara, at provincial level for period 2014-2015, was in category surplus. However, there was a category minus at district level that is Tarakan District. Low production of cereals due to inadequate agricultural land, particularly paddy field, were considered as main factor of the food insufficiency. Agriculture is considered as one of primary sector but not the leading sector. The leading sector in Kalimantan Utara is mining. Within the agriculture sector, instead of food crops, estate plantation is still main sub sector to support the regional income. It was reflected by the configuration of the land use. Forest and estate plantation were predominant land use in Kalimantan Utara Province. This condition and situation may not considered as serious issues currently, since the number of population is still low despite the annual increasing trend. However, to develop preparedness regarding the potential disaster e.g. climate change, which will affect local as well as global food production, further attention must be paid to the issue of food insufficiency

\section{Acknowledgments}

The authors are grateful for financial support by Ministry of Research, Technology and Higher Education, Republic of Indonesia trough "Penelitian Unggulan Perguruan Tinggi (PUPT)" grant research, and The Institute for Research and Community Services (LPPM) Universitas Gadjah Mada. 


\section{References}

[1] BKPRI, 2014, Pedoman Sistem Kewaspadaan Pangan Dan Gizi Tingkat Kabupaten/Kota, Badan Ketahan Pangan Republik Indonesia Indonesian Ministry of Agriculture.

[2] BPS, 2016, Kalimantan Utara dalam Angka Tahun 2016 (Kalimantan Utara in Figures), Badan Pusat Statistik Kalimantan Utara.

[3] BPS, 2015, Kalimantan Utara dalam Angka Tahun 2015 (Kalimantan Utara in Figures), Badan Pusat Statistik Kalimantan Utara.

[4] BPS, 2016, Kota Tarakan dalam Angka Tahun 2016 (Tarakan City in Figures), Badan Pusat Statistik Kalimantan Utara.

[5] BPS, 2015, Kota Tarakan dalam Angka Tahun 2015 (Tarakan City in Figures), Badan Pusat Statistik Kalimantan Utara.

[6] FAO, 2008, An Introduction to the Basic Concepts of Food Security, Food and Agriculture Organization of the United Nations, Rome, Italy.

[7] Leroy, J.L., Ruel, M., Frongillo, E.A., Harris, J., and. Ballard, T.J., 2015, Measuring the Food Access Dimension of Food Security: A Critical Review and Mapping of Indicators. Food and Nutrition Bulletin Vol. 36(2) 167-195 https://doi.org/10.1177/0379572115587274

[8] Ye,L., Xiong, W., Li,Z., Yang,P., Wu, W., Yang,G., Fu,Y., Zou,J., Chen, Z., Ranst, E.V., and Tang,H., 2013, Climate change impact on China food security in 2050, Agron. Sustain. Dev. (33) https://doi.org/10.1007/s13593-012-0102-0.

[9] Reif,C., Lana, M., Graef, F., Ottfried, Dietrich, Schindler, J., Helming, K., Hannes, Koenig and Siebe, S., 2015, Combining analytical methods for assessing food security across the food value chain, A conceptual integrated approach, Outlook on Agriculture Vol 44, No 1. 